\title{
Clinical Outcomes After Topography-Guided Refractive Surgery in Eyes with Myopia and Astigmatism - Comparing Results with New Planning Software to Those Obtained Using the Manifest Refraction [Response To Letter]
}

This article was published in the following Dove Press journal: Clinical Ophthalmology

\section{Paul Michael Mann' \\ Paul M Mann II' \\ Phillip Brunson' \\ Richard Potvin (1D) ${ }^{2}$}

'Mann Eye Institute and Laser Centers, Houston, TX, USA; ${ }^{2}$ Science in Vision, Bend, OR, USA
Correspondence: Phillip Brunson Mann Eye Institute and Laser Centers, 5 II 5 Main Street, Suite \#300, Houston, TX, 77002, USA

Email phillip.brunson@manneye.com

\section{Dear editor}

We thank Dr. Motwani for his interest in our study. While he mentions a second study that follows the same "script", we would point out that data from our practice was not included in that study. The similarity appears related to the fact that both studies were retrospective, where data are limited and the outcome measures are patient-based, generally consisting of the postoperative refraction and visual acuity data in the clinical records. Our primary goal was merely to determine if use of the Phorcides Analytical Engine (Phorcides) was improving outcomes in our practice.

We do not believe LYRA was mischaracterized in the manuscript, as the comment (reworded and slightly less clear in Dr. Motwani's letter) was meant only to indicate that both topographic and refractive data were being used to plan the laser treatment.

We did not collect the detailed topographic and Zernike data that he suggests is important. That was not the intent of the study. Nor did we provide a detailed scientific explanation for our results, outside of the fact that we know that Phorcides is designed to smooth the anterior cornea. Neither of these deficiencies is unusual in a retrospective analysis of clinical outcomes, nor do they materially affect the results we reported. As to the "assumptions" related to Phorcides treatment vis a vis lens changes, posterior astigmatism and epithelial compensation, we would refer Dr. Motwani to the developers of Phorcides for detailed explanations. We chose to use Phorcides because it was an objective method to implement topography-guided LASIK treatment and we believed it would improve our outcomes. The study we completed has confirmed the latter to us.

Dr. Motwani quotes his published manuscript ${ }^{1}$ suggesting lower accuracy with Phorcides when there are greater differences between the manifest and Contoura measured astigmatism. We did not observe that in our data set. His analysis may not be relevant because he was using an early experimental version of the Phorcides software and had not taken the mandatory training course (confirmed for us by the developers of Phorcides). In addition, there are known limitations of comparing 
back-calculated astigmatism data to actual results, as results appear biased in favor of the actual planning method used (the "home field advantage", as one surgeon characterizes it). ${ }^{2}$ Unfortunately, a concise summary of the nature of this bias has not yet been published.

Dr. Motwani concludes with his observations related to his experience surgical planning with Phorcides. While interesting, they in no way detract from our findings. In a well-matched set of eyes, we found Phorcides provided sufficient clinical benefit to our patients to justify its continued use in our practice.

\section{Disclosure}

Richard Potvin is a consultant to Alcon and Carl Zeiss Meditec (though not in the area of refractive surgery for either company). Phillip Brunson is a consultant to Allergan Pharmaceuticals, Eyevance Pharmaceuticals and Novartis Pharmaceuticals. Paul Michael Mann and Paul M Mann II report grants from Alcon, during the conduct of the study. The authors report no other conflicts of interest in this communication.

\section{References}

1. Motwani M. Predictions of residual astigmatism from surgical planning for topographic-guided LASIK based on anterior corneal astigmatism (Lyra protocol) vs the phorcides analytic engine. Clin Ophthalmol. 2020;14:3227-3236. doi:10.2147/OPTH.S272085

2. Hill W, Osher R, Cooke D, et al. Simulation of toric intraocular lens results: manual keratometry versus dual-zone automated keratometry from an integrated biometer. J Cataract Refract Surg. 2011;37 (12):2181-2187. doi:10.1016/j.jcrs.2011.06.028

Dove Medical Press encourages responsible, free and frank academic debate. The content of the Clinical Ophthalmology 'letters to the editor' section does not necessarily represent the views of Dove Medical Press, its officers, agents, employees, related entities or the Clinical Ophthalmology editors. While all reasonable steps have been taken to confirm the content of each letter, Dove Medical Press accepts no liability in respect of the content of any letter, nor is it responsible for the content and accuracy of any letter to the editor.

\section{Publish your work in this journal}

Clinical Ophthalmology is an international, peer-reviewed journal covering all subspecialties within ophthalmology. Key topics include: Optometry; Visual science; Pharmacology and drug therapy in eye diseases; Basic Sciences; Primary and Secondary eye care; Patient Safety and Quality of Care Improvements. This journal is indexed on PubMed
Central and CAS, and is the official journal of The Society of Clinical Ophthalmology (SCO). The manuscript management system is completely online and includes a very quick and fair peer-review system, which is all easy to use. Visit http://www.dovepress.com/ testimonials.php to read real quotes from published authors. 